\title{
Impregnated Active Carbon-Shelf Life Studies and Its Evaluation Against Cyanogen Chloride with and without Canister
}

\author{
Beer Singh^, Amit Saxena, Avanish Kumar Srivastava, \\ Devendra Kumar Dubey and Arvind Kumar Gupta
}

\author{
Defence Research and Development Establishment, Jhansi road, Gwalior-474002 (MP), India \\ •e-mail: beerbs5@rediffmail.com \\ (Received August 13, 2007; Accepted September 27, 2007)
}

\begin{abstract}
Samples of active carbon of $1150 \mathrm{~m}^{2} / \mathrm{g}$ surface area were impregnated with ammoniacal salts of copper, chromium and silver, with and without triethylenediamine. The samples of impregnated carbon were aged at $50^{\circ} \mathrm{C}$, with and without $90 \% \mathrm{RH}$ (relative humidity), for a little more than one year and chemically evaluated periodically. Initially copper (II) and chromium (VI) reduced very fast in the samples in humid atmosphere to the extent of $30 \%$ and $60 \%$ respectively in four months. These values were found to be unaffected by the presence of triethylenediamine (TEDA) indicating that the chemical did not retard the reduction process of chromium (VI) and copper (II). However, in the absence of humidity the reduction of the impregnants was significantly less $(10-12 \%, \mathrm{w} / \mathrm{w})$ in four months. It was quite evident; therefore, that the moisture was mainly responsible for the reduction of chromium (VI) and copper (II) species in impregnated carbons. The prolonged ageing of the samples with and without triethylenediamme after four months with and without humid atmosphere showed that the extent of reduction of chromium (VI) was very low, i.e. 5-10\% and of copper (II) was $2-25 \%$. Silver is not reduced due to carbon, as it remained unchanged in concentration on storage. The impregnated carbon samples $(100 \mathrm{~g})$ without triethylenediamine, which were aged at room temperature for 5 years in absence of humidity and unaged when evaluated against cyanogen chloride $(\mathrm{CNCl})$ at a concentration of $4 \mathrm{mg} / \mathrm{L}$ and airflow rate of $30 \mathrm{lpm}$ showed a high degree of protection (80- 110 minutes).
\end{abstract}

Keywords : Activated carbon, impregnated carbons, impregnation and cyanogen chloride

\section{Introduction}

Chemical warfare (CW) agents are highly toxic chemicals, which are used in wars to harm or incapacitate human. Protection against them can be achieved by using suitable material, which can perform the function of physisorption followed by chemisorption in filtration systems. Impregnated active carbon has been proven as the best adsorbent material for filtration systems [1]. This initially adsorbs the CW agent (physisorption) and then degrades it by reacting with it to give non toxic products. One such material, active carbon, impregnated with ammoniacal salts of copper (II), chromium (VI) and silver (I) salts has been proven to be an efficient material for the removal of low boiling and low molecular weight gases such as cyanogen chloride, hydrogen cyanide, phosgene, etc [1-4]. Under ambient conditions, this adsorbent material hydrolyses cyanogen chloride and phosgene effectively to convert them into non-toxic products.

On aging in hot and humid atmosphere, these material lose their protection capacity against chemical warfare agents due to reduction of copper (II), chromium (VI) to their lower oxidation states [5-9]. The literature [5-8] reveals the characterization of impregnated carbons aged under hot and humid conditions/atmosphere for the reduction of copper
(II), chromium (VI), and their concentration and chemical compositions. This investigation was undertaken to examine the reduction of copper (II), chromium (VI), silver (I) content in bulk impregnated carbon with triethylenediamine, The objective of the study was also to investigate the ability of TEDA to provide stability to chromium (VI) in impregnated carbon on storage.

\section{Experimental}

Active carbon of coconut shell origin, $12 \times 30 \mathrm{BSS}$ mesh size and $1150 \mathrm{~m}^{2} / \mathrm{g}$ surface area from M/s Active Carbon India Ltd. Hyderabad, was impregnated with ammoniacal solution of copper (II), chromium (VI), silver (I) salts [10] alone and along with TEDA. The impregnated carbons were characterized for surface area, copper (II), chromium (VI), total chromium and silver contents [11]. The results are summarized in Table 1. Sample I was prepared by impregnating carbon first with copper, chromium, silver and then with TEDA, however, sample II was prepared by impregnating carbon first with TEDA and then with metal impregnants.

Impregnated carbon containing-copper (II), chromium (VI) 
Table 1. Characterization of Impregnated Carbons

\begin{tabular}{ccccccc}
\hline Sample & TEDA (\%) & $\begin{array}{c}\text { Silver }(\%) \\
\text { found calcd }\end{array}$ & $\begin{array}{c}\text { Copper }(\%) \\
\text { found calcd. }\end{array}$ & $\begin{array}{c}\text { Chromium } \\
\text { (VI) }(\%)\end{array}$ & $\begin{array}{c}\text { Total Chromium } \\
(\%) \text { found calcd. }\end{array}$ & $\begin{array}{c}\text { Surface area }\left(\mathrm{m}^{2} / \mathrm{g}\right) \\
\text { I }\end{array}$ \\
\hline II & 3 & 0.240 .24 & 6.36 .5 & 2.08 & 2.72 .8 & 950 \\
III & Nil & 0.150 .16 & 6.36 .5 & 2.26 & 2.62 .8 & 960 \\
IV & 3 & 0.170 .16 & 6.46 .5 & 1.97 & 2.72 .8 & 1030 \\
\hline
\end{tabular}

Sample I \& II were dried at $110^{\circ} \mathrm{C}$ for $6 \mathrm{hrs}$.

Sample III \& IV were dried at $135^{\circ} \mathrm{C}$ for $6 \mathrm{hrs}$.

Table 2. Cyanogen Chloride Protection Time of Copper, Chromium and Silver Impregnated Carbon with and without Canister

\begin{tabular}{|c|c|c|c|c|c|}
\hline S1. No. & Sample & $\begin{array}{c}\mathrm{N}_{2} \text { Flow rate } \\
(\mathrm{lpm})\end{array}$ & $\begin{array}{l}\mathrm{CNCl} \text { conc. } \\
(\mathrm{mg} / \mathrm{l})\end{array}$ & $\begin{array}{l}\mathrm{CNCl} \text { protection time } \\
(\mathrm{min})\end{array}$ & $\begin{array}{c}\text { Corresponding } \mathrm{CNCl} \\
\text { protection time at } \\
4 \mathrm{mg} / \mathrm{l} \mathrm{CNCl} \mathrm{conc.(mg/l)}\end{array}$ \\
\hline 1 & $\begin{array}{c}\text { Carbon } \\
\text { (4.7 gm, } 2 \mathrm{~cm} \text { bed height) }\end{array}$ & 1.2 & 5.03 & 59.38 & 74.5 \\
\hline 2 & $\begin{array}{c}\text { Carbon } \\
\text { (4.7 gm, } 2 \mathrm{~cm} \text { bed height) }\end{array}$ & 1.2 & 6.43 & 51.58 & 83.00 \\
\hline 3 & $\begin{array}{c}\text { Carbon } \\
\text { (12.3 gm, } 5.0 \mathrm{~cm} \text { bed height })\end{array}$ & 6.3 & 29.24 & 14.7 & 107.2 \\
\hline 4 & $\begin{array}{c}\text { Carbon } \\
\text { (12.3 gm, } 5.0 \mathrm{~cm} \text { bed height })\end{array}$ & 6.3 & 13.87 & 31.4 & 108.9 \\
\hline 5 & $\begin{array}{c}\text { Carbon } \\
\text { (12.3 gm, } 5.0 \mathrm{~cm} \text { bed height })\end{array}$ & 0.6 & 100.8 & 24.5 & 616.9 \\
\hline 6 & $\begin{array}{c}\text { Carbon } \\
\text { (12.3 gm, } 5.0 \mathrm{~cm} \text { bed height })\end{array}$ & 30.0 & 29.59 & 5.1 & 37.7 \\
\hline 7 & (12.3 gm, $5.0 \mathrm{~cm}$ bed height) & 30.0 & 7.41 & 19.58 & 36.1 \\
\hline 8 & Canister $^{\mathrm{a}}$ & 30.0 & 69.94 & 2.0 & 35.0 \\
\hline 9 & Canister $^{\mathrm{a}}$ & 30.0 & 6.37 & 85.8 & 136.0 \\
\hline 10 & Canister $^{\mathrm{b}}$ & 30.0 & 10.69 & 38.28 & 102.3 \\
\hline 11 & Canister $^{\mathrm{b}}$ & 30.0 & 9.47 & 42.7 & 110.5 \\
\hline
\end{tabular}

(a) Canister from M/s Pradeep Packages, Bombay, aged for 5 years, at ambient conditions, with plugs intact at both ends.

(b) Canister from M/S Purolit Filters, Bombay.

and silver (I) salts with and without TEDA were stored at $50^{\circ} \mathrm{C}$ and separately, at $50^{\circ} \mathrm{C}$ and $90 \% \mathrm{RH}$. The samples were then taken out at regular intervals and analyzed for impregnants using wet analytical methods [11] and the results summarized in Fig. 2, 3 and 4 except for silver, which remained unchanged during aging process. Copper (II), chromium (VI) and silver (I) salts impregnated carbons as such and loaded in canisters were also evaluated against cyanogen chloride using the test schematic of which was shown in Fig. 1, and the results in Table 2.

\section{Evaluation of carbon/canister against cyanogen chloride}

As per Fig. 1 cyanogen chloride was taken from cylinder (4) through valve (5) and flow meter (6), mixed with nitrogen in a mixing chamber (7). Nitrogen $\left(\mathrm{N}_{2}\right)$ was taken in required flow rate (Table II) from cylinder (1) through valve (2) and flow meter (3). $\mathrm{CNCl}_{-} \mathrm{N}_{2}$ mixture was passed through two traps $(17 \& 18)$. Methanolic sodium hydroxide $\left(20 \mathrm{~mL}\right.$ methanol $+25 \mathrm{~mL} 10^{-2} \mathrm{~N}$ sodium hydroxide) at 100

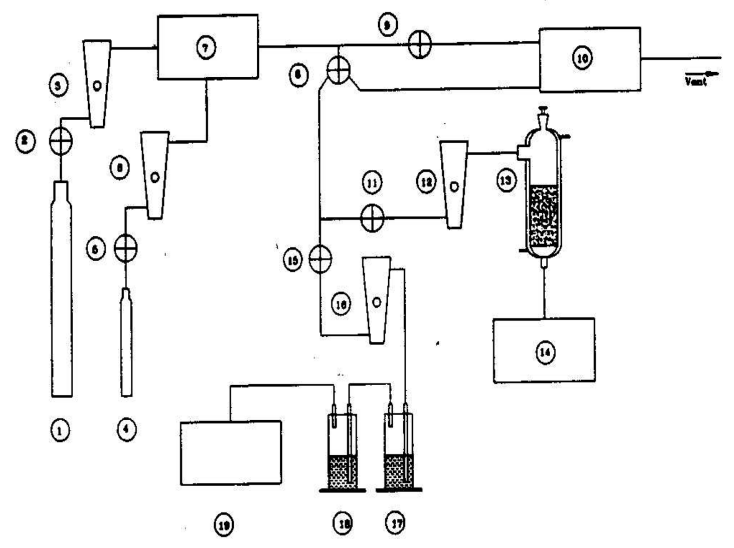

1. Nitrogen Cylinder $2,5,9,11 \& 15$ Control Valves $3,6,12 \& 16$ Rotameters 7 Mixing Chamber

10 Scrubher

8 Two way valve

13 Carbon coloumn/canister $14 \& 19$ Detetctor systems $17 \& 18$ Cyanogen chloride traps

Fig. 1. Experimental set-up for $\mathrm{CNCl}$ adsorption. 


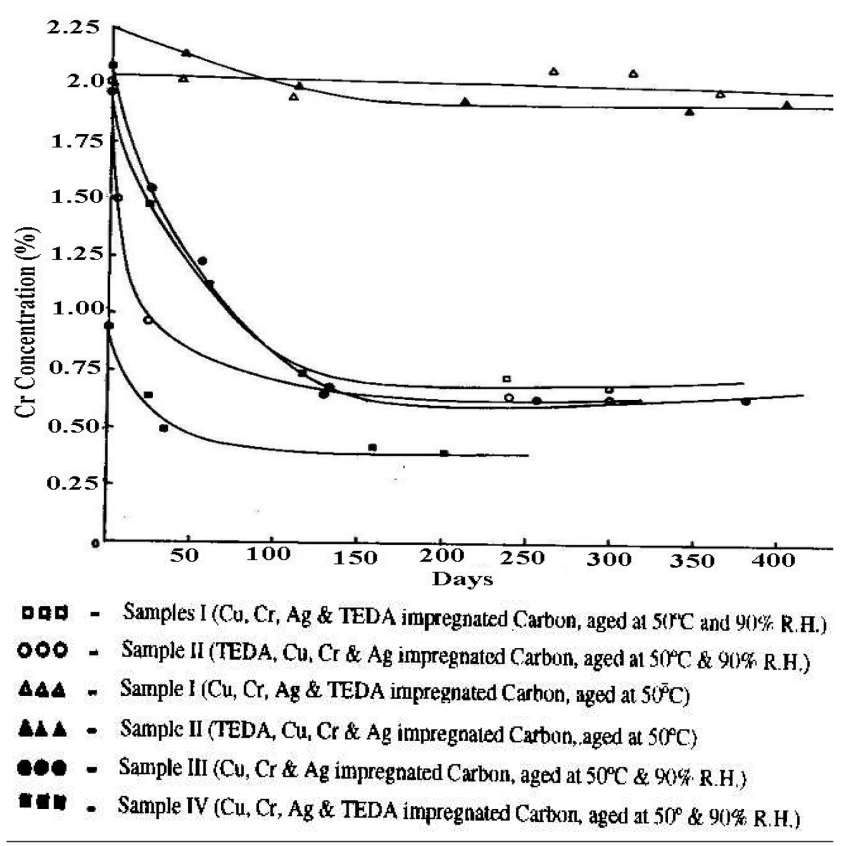

Fig. 2. Chromium (VI) concentration in aged impregnated carbon.

$\mathrm{mL} / \mathrm{min}$ flow rate measured through flow meter (16) and controlled through a valve (15). This solution was used to measure the concentration of $\mathrm{CNCl}$ in CNCI- $\mathrm{N}_{2}$ mixture following the standard method [12].

CNCl- $\mathrm{N}_{2}$ mixture was passed also through a test specimen (carbon column/canister No. 13) and a flow meter (12) by controlling the flow rate using a control valve (11). The $\mathrm{CNCl}$ breakthrough was monitored at the outlet of test specimen and $\mathrm{CNCl}$ concentration measuring traps with a detector paper [14-19] prepared using standard method. Time difference between the instant of the breakthrough time and beginning time gave the protection time of carbon/ canister against $\mathrm{CNCl}$.

\section{Results and discussion}

Function of impregnated carbon versus aging is shown in Figure 2, 3 and 4 in terms of chromium (VI), total chromium and copper (II) respectively.

Table 1 shows the impregnants in carbon and also drying temperature. Carbon after impregnation with ammoniacal solutions of copper (II), chromium (VI) and silver (I) salts is dried at $130^{\circ}$ to $140^{\circ} \mathrm{C}$ for 6 to $8 \mathrm{hrs}$ which results in 70 to $75 \%$ chromium(VI) loading in impregnated carbon. However, the carbon with the above impregnants and with triethylenediammine when heated at $130^{\circ} \mathrm{C}$ to $140^{\circ} \mathrm{C}$, chromium (VI) content was found to bare reduced significantly and only $35 \%$ chromium (VI) Of total chromium (VI) loading could be achieved (Table I, sample IV). It was

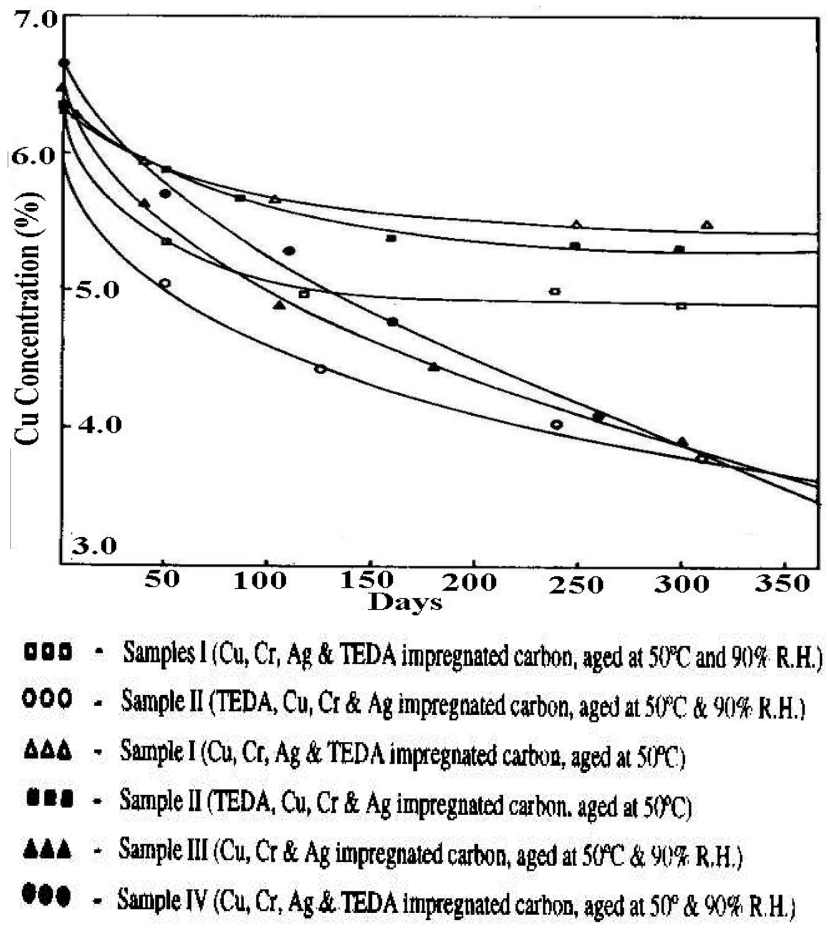

Fig. 3. Copper concentration in aged impregnated carbon.

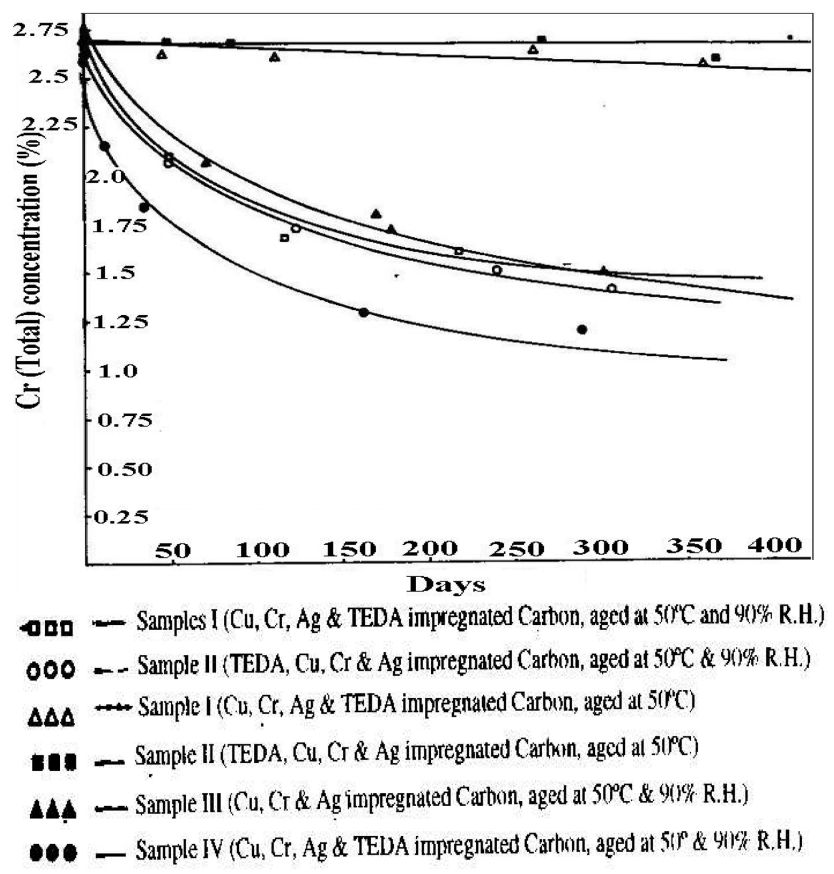

Fig. 4. Chromium (total) concentration in aged impregnated carbon.

probably due to the decomposition of a complex formed by chromium (VI) and triethylenediammine. This was confirmed when a compound crystallized (green shining needles) from a mixture of two moles of chromiumtrioxide and one 
mole of triethylenediammine from aqueous solution, was checked for its melting point, and which decomposed at $120^{\circ} \mathrm{C}$. In view of this, the carbon was impregnated with copper (II), chromium (VI) and silver (I) salts and triethylenediammine and dried at $110^{\circ} \mathrm{C}$ below the decomposition temperature of chromium (VI) compound of triethylenediamine. The required loading of chromium (VI) (70 to $75 \%$ ) out of the total chromium (VI) could be achieved in impregnated carbon on which is of utmost importance as it is mainly responsible in the detoxification of cyanogen chloride [13], phosgene, etc.

In samples I \& II (Table 1), the only difference is the order of addition of triethylenediammine, Sample I was impregnated with metal salts first and then with triethylenediammine while for sample II the order was reversed. However, the sample II showed further improvement in chromium (VI) loading and this indicated that this is a more suitable way of impregnating carbon.

The carbons thus impregnated (Table 1) were aged under two different conditions. One was their storage at $50^{\circ} \mathrm{C}$ and another, at $50^{\circ} \mathrm{C}$ and $90 \%$ RH. Fig. 2 gives the aging process of chromium (VI) and indicates that at $50^{\circ} \mathrm{C}$ and $90 \% \mathrm{RH}$, chromium (VI) reduction due to carbon in samples I \& II was rapid and significant during the initial period of four months (64 to 70\%). Afterwards it almost leveled off in next eight months additionally to $2-3 \%$. The reduction of chromium (VI) in sample II was very high initially, i.e. 55\% in 30 days. The same sample when aged at $50^{\circ} \mathrm{C}$ in absence of humidly, chromium (VI) reduced very slowly, in sample I, the reduction of chromium (VI) was very less, i.e. $5 \%$ in one year, However, in sample II the chromium (VI) reduction was $12.5 \%$ during the initial 4 months giving overall reduction of $15.4 \%$ in a year. In sample III where triethylenediammine was not present, the chromium(VI) reduction was $63 \%$ during the first four months and in next eight months the reduction was merely $5 \%$ under chamber conditions of $50^{\circ} \mathrm{C}$ and $90 \% \mathrm{RH}$. The results indicated that the absence of TEDA in impregnated carbon neither caused fast aging of the material nor its presence retarded the chromium (VI) reduction. Sample IV, which initially contained a very low loading of chromium (VI) after heating at $140^{\circ} \mathrm{C}$ for 6 hrs showed its reduction to chromium (III) by $47 \%$ in 40 days which increased to $59 \%$ within four months and later negligible reduction of chromium (VI) in last next eight months. Probably moisture catalyses/activates the chromium (VI) and copper (II) reduction to their lower oxidation species.

The data indicated that triethylenediammine did not provide any stability to chromium (VI) species in impregnated carbon in hot and humid atmosphere. This was also confirmed by the fact that impregnated carbon/canister/filters (NBC) can be stored at $30^{\circ} \mathrm{C}$ away from moisture for a period of 5 years as the reduction of chromium (VI) to chromium (III) is hardly $5 \%$ to $15 \%$. However, under hot and humid condition, i.e. $30^{\circ} \mathrm{C}$ and $90 \%$ RH the sample storage life could reduce, if functional requirement are to be satisfied.

Fig. 3 indicates that the reduction of copper (II) to its lower oxidation state by carbon under chamber conditions of $50^{\circ} \mathrm{C}$ and $90 \% \mathrm{RH}$ was a continuous process which initially was rapid. In samples I, II, III \& IV the initial reduction of copper (II) during four months was 20.3 to $28.7 \%$ and except sample I, it increased to 42 to $51.3 \%$ in other samples in one year. In sample I, it increases to $22.8 \%$ from $20.3 \%$ during the eight next months. The data of chromium (VI) and copper (II) reduction (Fig. $2 \& 3$ ) showed that the sample I where carbon was impregnated with TEDA after $\mathrm{Cu}, \mathrm{Cr} \& \mathrm{Ag}$. the reduction of chromium (VI) and copper (II) reduction by carbon on aging in sample I and II indicates that the carbon should be impregnated as per the method of sample I preparation.

Fig. 3 also indicated that under chamber conditions of $50^{\circ} \mathrm{C}$ and without moisture/humidity reduction of copper (II) was slow at 10.4 to $10.9 \%$ during the initial four months and 11.9 to $16.6 \%$ in the next 8 months after slow and continuous reduction.

Total chromium content changes to some species, which are not extractable with sodium hydroxide during aging process. Fig. 4 shows that under chamber conditions of $50^{\circ} \mathrm{C}$ and $90 \%$ RH this change was 34 to $45.5 \%$ dining 120 days, which initially was very rapid. This increases to 46.3 to $60 \%$ in next eight months. However, at chamber conditions of $50^{\circ} \mathrm{C}$ and without humidity it was hardly significant $(0$ to $6.8 \%$ ) during one year, probably due to the presence of triethylenediamine. In samples I \& II under condition of $50^{\circ} \mathrm{C}$ and $90 \% \mathrm{RH}$ it was 34 to $36 \%$ initially during a period of four months. However, later in the next eight months the change seems to be same as the sample in which TEDA was not impregnated. This indicates that TEDA does not retard the reduction of chromium (VI) and copper (II) in impregnated carbon. Silver when analyzed in the aged samples I, II, III, IV at $50^{\circ} \mathrm{C}$ with and without humidity showed no change indicating that silver does not undergo reduction process.

Table 2 describes the cyanogen chloride protection achieved by carbon as such or in canister. The data indicated that at a higher concentration of cyanogen chloride the protection against cyanogen chloride was less due to the low contact time of adsorbents with impregnated carbon (Table 2, Sr. No.8). The results showed that the canister containing $100 \mathrm{gm}$ of $\mathrm{Cu}$, $\mathrm{Cr} \& \mathrm{Ag}$ impregnated carbon can protect for more than 100 minutes at $30 \mathrm{lpm} \mathrm{N} 2$ flow rate and $4 \mathrm{mg} / 1 \mathrm{CNCl}$ concentration. The required protection time, however, is 30 minutes only. The same applied to the canister, which was stored for five years at ambient conditions (room temperature) with both the canister plugs intact in their places. The carbon bed height, flow rate and $\mathrm{CNCl}$ con- centration were found to be affecting the $\mathrm{CNCl}$ protection time. 


\section{Conclusion}

This study enabled us to develop a suitable impregnation method for carbon suitably with copper, chromium, silver and triethylenediammine. The resulting impregnated carbon contained the required chromium (VI) in required amount (60 to $70 \%$ of the total chromium (VI) loading). The study also confirmed that if TEDA was to be impregnated along with other impregnants to achieve additional $\mathrm{CNC1}$ protection, it should be impregnated first with metal impregnants and then TEDA in the second step as the aging of the carbon thus impregnated is slower to the carbon impregnated otherwise. The shelf life of copper, chromium and silver impregnated carbon, as such and in NBC canister and filter if stored at $30^{\circ} \mathrm{C}$ away from the moisture was more than five years. This was in confirmation with the result offered by a canister stored for five years at room temperature (25 to $40^{\circ} \mathrm{C}$ ) and free from humidity, with no deterioration of $\mathrm{CNCl}$ protection capacity. However, in the presence of moisture (RH 90\%), its shelf life decreases and the functional requirement will have to be adjusted accordingly. The study indicated that humidity was mainly responsible for the reduction of copper (II) and chromium (VI) in impregnated carbon on storage.

\section{Acknowledgements}

The authors thank Director, DRDE Gwalior for permitting to carry out and publish this work.

\section{References}

[1] Noyes, W. A. Jr. "Military problems with aerosols and non-persistent gases", Vol. 1, Washington DC, Summary Technical Report of the National Defence Research Committee, Division 10, 1946, 40.

[2] Aharoni, C.; Barnir, Z. J. Am. Ind. Hyg. Assoc. 1978, 39, 334.

[3] Barnir, Z.; Aharoni, C. Carbon 1975, 13, 363.

[4] Poziomek, E. J.; Mackay, R. A.; Barret, R. P, Carbon 1975, 13, 259.

[5] Hammarstrom, J. L.; Sacco, A. J. Catal. 1988, 112, 267.

[6] Bac, N.; Hammarstrom, J. L.; Sacco, A. Carbon 1987, 25 , 545.

[7] Ehrburger, P.; Heniin, J. M.; Lahye, J. J.Catal. 1986, 100, 429.

[8] Ehrburger, P.; Dentzer, R. J.; Lahaye, J.; Dziedzini, P.; Fangat. Carbon, 1990, 28, 113.

[9] Ehrburger, P.; Dentzer, R. J.; Lahaye, J.; Dziedzini, P.; Fangat. Carbon, 1991, 29, 297.

[10] Singh, B.; Madhusudanan, S.; Padmakumar, C. G.; Sachan, S. R. S.; Pandey, S. K.; Agarwal, S. Def. Sci. J. 1998, 48, 365 .

[11] Singh, B.; Madhusudanan, S.; Padmakumar, C. G.; Sachan, S. R. S.; Pandey, S. K.; Agarwal, S. Def. Sci. J. 1998, 48, 365 .

[12] Smisek, M.; Cerny, S. “Active Carbon”, Elsevier publication, Amsterdam, 1970, 188.

[13] Ross, M. M.; Colton, R. J.; Deitz, V. R. Carbon, 1989, 27, 492. 